\title{
Acute kidney injury 2016: diagnosis and diagnostic workup
}

\author{
Marlies Ostermann ${ }^{1^{*}}$ (D) and Michael Joannidis ${ }^{2^{*}}$
}

\begin{abstract}
Acute kidney injury (AKI) is common and is associated with serious short- and long-term complications. Early diagnosis and identification of the underlying aetiology are essential to guide management. In this review, we outline the current definition of AKI and the potential pitfalls, and summarise the existing and future tools to investigate AKI in critically ill patients.
\end{abstract}

\section{Background}

Acute kidney injury (AKI) is a syndrome characterised by a rapid (hours to days) deterioration of kidney function. It is often diagnosed in the context of other acute illnesses and is particularly common in critically ill patients. The clinical consequences of AKI include the accumulation of waste products, electrolytes, and fluid, but also less obvious effects, including reduced immunity and dysfunction of non-renal organs (organ cross-talk) [1].

The impact and prognosis of AKI vary considerably depending on the severity, clinical setting, comorbid factors, and also geographical location. There is increasing evidence that AKI is associated with serious short- and long-term complications, in particular increased mortality and morbidity, the development of chronic kidney disease (CKD), and high financial healthcare costs. As such, AKI is now recognized as a major public health problem $[2,3]$.

Rapid diagnosis and appropriate diagnostic workup are essential to identify those types of AKI where specific therapies and interventions are available to reverse the injurious process within the kidneys. This review will summarise the key aspects of diagnosis and diagnostic work-up with particular focus on patients in the intensive care unit (ICU).

\footnotetext{
* Correspondence: Marlies.Ostermann@gstt.nhs.uk;

michael.joannidis@i-med.ac.at

${ }^{1}$ Department of Critical Care Medicine, King's College London, Guy's \& St Thomas' Foundation Hospital, Westminster Bridge Road, London, UK ${ }^{2}$ Division of Intensive Care and Emergency Medicine, Medical University of Innsbruck, Anichstr. 35, Innsbruck, Austria
}

\section{Diagnosis of AKI}

The diagnosis of AKI is traditionally based on a rise in serum creatinine and/or fall in urine output. The definition has evolved from the Risk, Injury, Failure, Loss, End-stage (RIFLE) criteria in 2004 to the AKI Network (AKIN) classification in 2007 [4, 5]. In 2012, both were merged resulting in the Kidney Disease Improving Global Outcomes (KDIGO) classification [6]. Accordingly, AKI is diagnosed if serum creatinine increases by $0.3 \mathrm{mg} / \mathrm{dl}$ $(26.5 \mu \mathrm{mol} / \mathrm{l})$ or more in $48 \mathrm{~h}$ or rises to at least 1.5 -fold from baseline within 7 days (Table 1). AKI stages are defined by the maximum change of either serum creatinine or urine output. The importance of both criteria was confirmed in a recent study in $>32,000$ critically ill patients which showed that short- and long-term risk of death or renal replacement therapy (RRT) were greatest when patients met both criteria for AKI and when these abnormalities persisted for longer than 3 days [7].

Several studies in various different patient populations have confirmed an association between stages of AKI and short- and long-term outcomes [8-13]. However, serum creatinine and urine output are markers of excretory function only and do not provide any information about any other roles of the kidney, i.e. metabolic, endocrine, or immunological functions. They are also not kidney specific and need to be interpreted within the clinical context. Some patients fulfil the AKI definition but do not have $\mathrm{AKI}$, and there are also patients with clear evidence of renal injury who do not meet the creatinine or urine criteria for AKI $[14,15]$ (Table 2).

\section{Limitations of creatinine-based criteria for AKI}

Serum creatinine is a metabolite of creatine, a molecule that is synthesized from the amino acids glycine and arginine in liver, pancreas, and kidneys and that serves as a rapidly mobilizable reserve of high-energy phosphates in skeletal muscle (Fig. 1). Creatinine production is determined by the amount of creatine generated in liver, pancreas, and kidneys, creatine ingested (i.e. intake of red meat) and muscle function. With a molecular weight 
Table 1 KDIGO definition and classification of AKI [6]

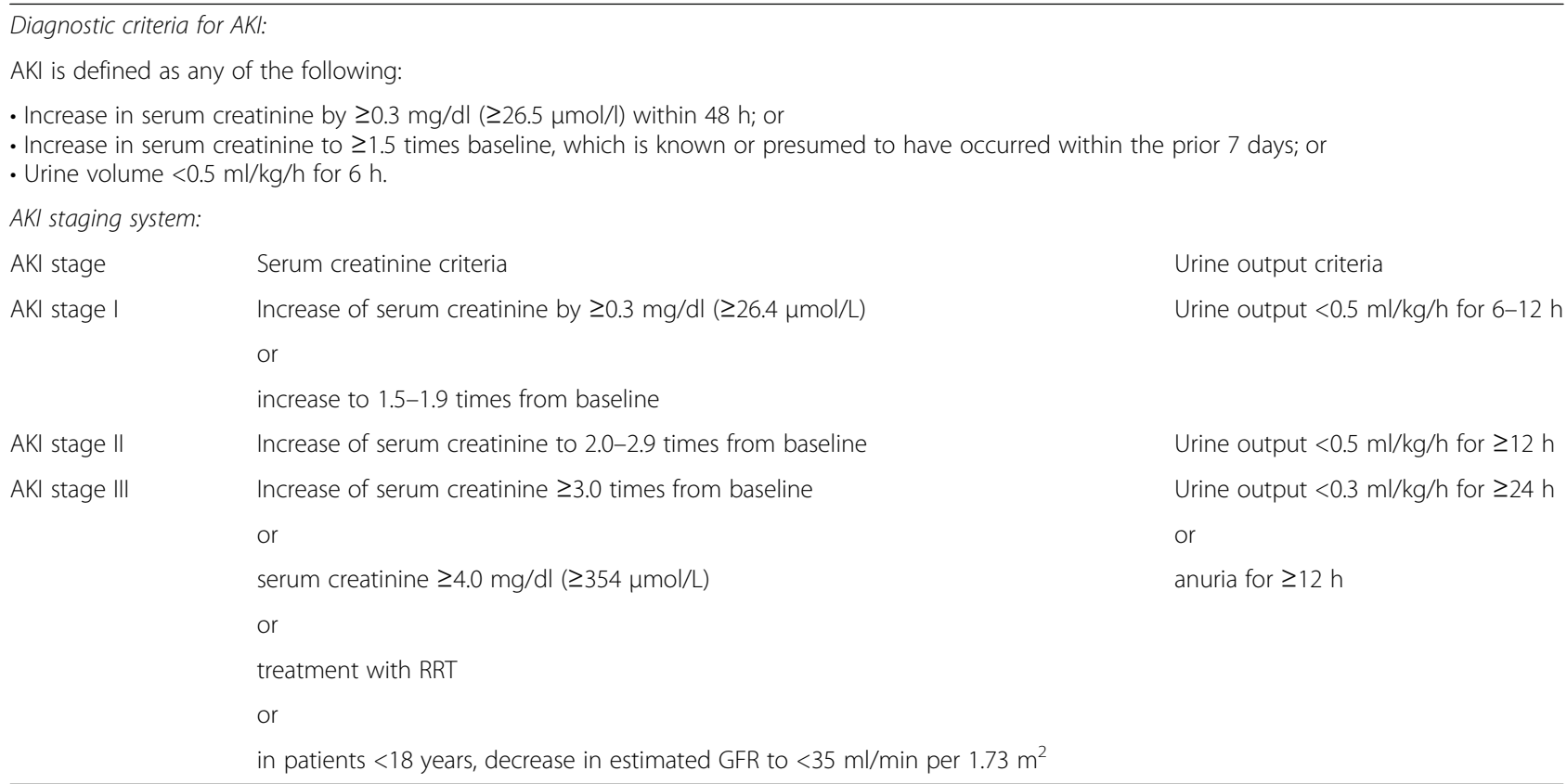

$A K I$ acute kidney injury, GFR glomerular filtration rate, KDIGO Kidney Disease Improving Global Outcomes, $R R T$ renal replacement therapy

of $113 \mathrm{Da}$, creatinine is freely filtered by the glomeruli. In health, it is produced at a constant rate and the rate of production is matched by the rate of renal excretion. However, large and sustained falls in production have been demonstrated during critical illness [16-18].

The role of creatinine as a marker of renal function is limited by the fact that its half-life increases from $4 \mathrm{~h}$ to 24-72 $\mathrm{h}$ if the glomerular filtration rate (GFR) decreases. As such, the serum concentration may take $24-36 \mathrm{~h}$ to rise after a definite renal insult. Furthermore, a true fall in GFR may not be adequately reflected by serum creatinine in patients with sepsis, liver disease, and/or muscle wasting $[15,17,18]$. Serum creatinine concentrations are also affected by drugs which compete with tubular secretion. In this case, serum creatinine levels may fluctuate without a change in renal function (Table 2). There is also no standardized laboratory method for quantifying serum creatinine, and substances like bilirubin or drugs may interfere with certain analytical techniques, more commonly with Jaffe-based assays.

Serum creatinine is measured as a concentration and is therefore affected by variations in volume status. As a

Table 2 Potential pitfalls of AKI diagnosis based on creatinine and urine criteria

\begin{tabular}{|c|c|}
\hline Clinical scenario & Consequence \\
\hline $\begin{array}{l}\text { Administration of drugs which interfere with tubular secretion of creatinine } \\
\text { (i.e. cimetidine, trimethoprim) }\end{array}$ & $\begin{array}{l}\text { Misdiagnosis of AKI (rise in serum creatinine without change in } \\
\text { renal function) }\end{array}$ \\
\hline Reduced production of creatinine (i.e. muscle wasting, liver disease, sepsis) & Delayed or missed diagnosis of AKI \\
\hline $\begin{array}{l}\text { Ingestion of substances which lead to increased generation of creatinine } \\
\text { independent of renal function (i.e. creatin, cooked meat) }\end{array}$ & Misdiagnosis of AKI \\
\hline Obesity & $\begin{array}{l}\text { Overdiagnosis of AKI if using actual weight when applying urine } \\
\text { output criteria }\end{array}$ \\
\hline Conditions associated with physiologically increased GFR (i.e. pregnancy) & Delayed diagnosis of AKI \\
\hline $\begin{array}{l}\text { Interference with analytical measurement of creatinine } \\
\text { (i.e. 5-fluorocytosine, cefoxitin, bilirubin) }\end{array}$ & $\begin{array}{l}\text { Misdiagnosis and delayed diagnosis of AKI (depending on the } \\
\text { substance) }\end{array}$ \\
\hline Fluid resuscitation and overload & Delayed diagnosis of AKI (dilution of serum creatinine concentration) \\
\hline Progressive CKD with gradual rise in serum creatinine & Misdiagnosis of AKI \\
\hline $\begin{array}{l}\text { Extrinsic creatinine administration as a buffer in medications } \\
\text { (i.e. in dexamethasone, azasetron) }\end{array}$ & Pseudo-AKI \\
\hline $\begin{array}{l}\text { Oliguria due to acute temporary release of ADH (i.e. post-operatively, nausea, pain) } \\
\text { enhanced by maximal sodium reabsorption in the setting of volume/salt depletion }\end{array}$ & Misdiagnosis of AKI \\
\hline
\end{tabular}




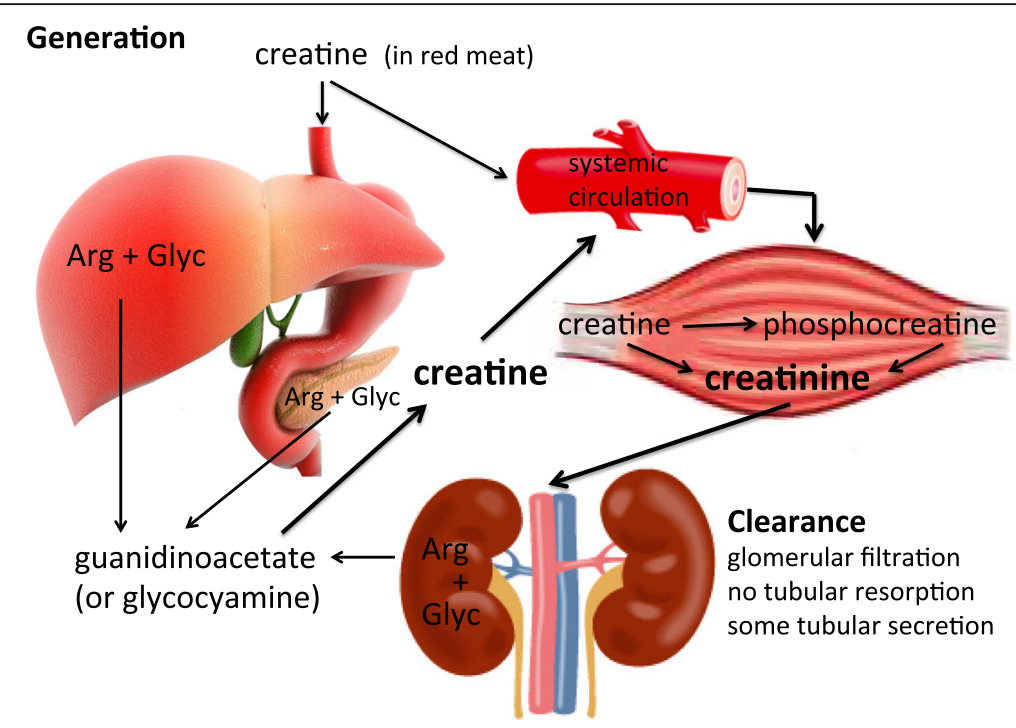

Fig. 1 Generation and clearance of creatinine. Arg arginine, Glyc glycine

result, the diagnosis of AKI may be delayed or missed in patients with significant fluid shifts or fluid overload $[19,20]$. This was highlighted in a post-hoc analysis of the Fluid and Catheter Treatment Trial [20]. It revealed that AKI was unmasked or classified differently in up to $18 \%$ of patients after serum creatinine levels were adjusted for net fluid balance and estimated total body water. Affected patients had mortality rates similar to those with AKI that was present before adjustment.

Another important limitation of all creatinine-based definitions of AKI is that they require a reference value to describe "baseline" renal function. Ideally, this value should reflect the patient's steady-state kidney function just before the episode of AKI. However, information on pre-hospital kidney function is not always available so that various surrogate estimates are frequently used. These may include inpatient results or the imputation of values such as back-calculating a baseline creatinine and using an estimated glomerular filtration rate (eGFR) of $75 \mathrm{ml} / \mathrm{min}$ per $1.73 \mathrm{~m}^{2}$ in patients with missing data [15]. Unfortunately, these methods can inflate as well as reduce the true incidence of AKI [21-23]. At present, there is no standard approach to determining baseline renal function.

Creatinine-based criteria for AKI often do not take into account underlying renal reserve. In patients with normal kidney function, a rise in serum creatinine by $0.3 \mathrm{mg} / \mathrm{dl}$ may indeed be due to an important reduction in GFR. In contrast, in patients with underlying CKD, absolute rises in serum creatinine represent variable changes in GFR, and a rise by $0.3 \mathrm{mg} / \mathrm{dl}$ may be within the acceptable daily variation and simply reflect an inconsequential change in GFR [24]. This is particularly relevant when diagnosing KDIGO AKI stage 3 which is defined by a rise in serum creatinine to $>4.0 \mathrm{mg} / \mathrm{dl}$ $(\geq 353.6 \mu \mathrm{mol} / \mathrm{l})$. A patient with a baseline serum creatinine of $3.9 \mathrm{mg} / \mathrm{dl}(345 \mu \mathrm{mol} / \mathrm{l})$ who experiences a creatinine rise by $0.3 \mathrm{mg} / \mathrm{dl}$ in $48 \mathrm{~h}$ would be classified as having KDIGO AKI stage 3, whereas such a rise would be defined as AKI stage 1 in a patient with normal baseline renal function [14].

Similar problems may occur when defining AKI stage 3 by the RRT criterion. The optimal timing of RRT for AKI is not known and clinical practice is very variable. As such, AKI staging depends directly on the decisionmaking process of the clinician rather than underlying renal function.

Finally, single serum creatinine values do not provide any information about specific stages of the AKI process. Importantly, they do not indicate whether a patient is still in the progression phase or if recovery has already begun. Also, eGFR formulae are not valid to determine renal function in AKI.

\section{Limitations of urine-based criteria for AKI}

Urine output is an important clinical marker [7, 25] but, like creatinine, is not renal specific. In fact, urine output may persist until renal function almost ceases. Similarly, oliguria may be an appropriate physiological response of functioning kidneys during periods of prolonged fasting, hypovolaemia, after surgery, and following stress, pain, or trauma [26-28]. In these situations, the action of anti-diuretic hormone (ADH) can result in the generation of very concentrated urine with osmolarities up to 1400 mmosm/l. Assuming a daily solute load of 700 mosmoles, the urine volume may physiologically decrease to $500 \mathrm{ml}$ (i.e. $0.28 \mathrm{ml} / \mathrm{kg} / \mathrm{h}$ in a $70 \mathrm{~kg}$ person) as a result of normal kidney function [28]. 
The KDIGO criteria for AKI are based on the presence of oliguria for a minimum of $6 \mathrm{~h}$ [6]. Several experts have questioned the validity of this arbitrary cut-off and suggest using either a longer minimum period (e.g. $12 \mathrm{~h}$ ) or a lower threshold for urinary output (e.g. $0.3 \mathrm{ml} / \mathrm{kg} / \mathrm{h}$ instead of $0.5 \mathrm{ml} / \mathrm{kg} / \mathrm{h}$ ) to reach sufficient specificity for diagnosing AKI $[14,29]$.

Finally, in obese patients, weight-based urine output criteria may be particularly misleading (Table 2). In fact, the European Renal Best Practice Guidelines (2012) recommend using the ideal weight rather than the true weight when calculating urine output in $\mathrm{ml} / \mathrm{min} / \mathrm{kg}$ to avoid an overdiagnosis of AKI [30].

\section{Adjunctive diagnostic tools to diagnose AKI}

In certain circumstances, it may be necessary to use additional tools to diagnose AKI, especially where creatinine and urine values change only slowly, are misleading, or cannot be interpreted accurately. This is particularly relevant for critically ill patients where the presence of fluid overload, muscle wasting, sepsis, and reduced effective circulating volume may completely mask the diagnosis of AKI.

\section{New AKI biomarkers}

Significant progress has been made in the detection and validation of new biomarkers for AKI to replace or complement serum creatinine. They vary in their anatomical origin, physiological function, time of release after the onset of renal injury, kinetics, and distribution [24, 25] (Table 3, Fig. 2). In addition to diagnosing AKI earlier, some of them may also provide information about the underlying aetiology and indicate different stages of the pathophysiological processes involved in AKI from acute injury to recovery [31].

Biomarkers for AKI can be stratified into markers primarily reflecting glomerular filtration (i.e. serum cystatin C), glomerular integrity (i.e. albuminuria and proteinuria), tubular stress (i.e. insulin-like growth factor binding protein 7 (IGFBP-7), tissue inhibitor metalloproteinase 2 (TIMP2)), tubular damage (i.e. neutrophil gelatinase-associated lipocalin (NGAL), kidney injury molecule-1 (KIM-1), N-acetyl- $\beta$ D-glucosaminidase (NAG), liver fatty acid-binding protein (L-FAB)), and intra-renal inflammation (i.e. interleukin-18) [32-37] (Table 3, Fig. 2).

The availability of these new markers has allowed the detection of subtle changes in renal function before serum creatinine rises and the identification of patients with evidence of kidney injury without a change in serum creatinine, i.e. "sub-clinical AKI" [34, 35, 38-40]. Of note, biomarker-positive, creatinine-negative patients appear to have a greater risk of complications, a longer stay in hospital and higher mortality compared to patients without a biomarker rise [38]. However, in certain situations, these events reflect higher severity of illness rather than degree of AKI [41].

The $10^{\text {th }}$ Acute Dialysis Quality Initiative (ADQI) Consensus Conference proposed to utilise both function and damage biomarkers in combination with traditional markers of renal function to better define and characterise AKI [35, 40] (Fig. 3). This approach appears to delineate the spectrum of AKI better than serum creatinine and urine output alone and has the potential to transform the way clinicians diagnose and manage patients with AKI.

Commercial kits for measurement of cystatin C, NGAL, IGFBP7 and TIMP-2 are available. To date, only cystatin $\mathrm{C}$ is routinely used in some hospitals. Cystatin $\mathrm{C}$ is a low molecular 13-kD inhibitor of lysosomal proteinases and extracellular inhibitor of cysteine proteases. It is produced in all nucleated cells and can be found in all tissues and body fluids. It is freely filtered in the glomeruli and then fully absorbed by the tubular cells and broken down. Since there is no tubular resorption or secretion, it is considered a better marker of GFR than serum creatinine. The main strength is that cystatin $C$ is less dependent on age, gender, muscle mass, and liver function [34, 42]. However, cystatin $\mathrm{C}$ levels have been reported to be altered in some patients with cancer, thyroid dysfunction, or steroid therapy, and smokers [43-46].

\section{Diagnosis of acute kidney disease}

AKI is defined as occurring over 7 days and CKD starts when kidney disease has persisted for more than 90 days. Based on epidemiological studies and histological case series, it is clear that some patients have a slow but persistent (creeping) rise in serum creatinine over days or weeks but do not strictly fulfil the consensus criteria for AKI $[47,48]$. To classify this phase between the early stage of AKI (first 7 days) and the onset of CKD (beyond 3 months), the KDIGO expert group proposed the term "acute kidney disease" (AKD) and suggested the following criteria: a GFR $<60 \mathrm{ml} / \mathrm{min} / 1.73 \mathrm{~m}^{2}$ for $<3$ months, a decrease in GFR by $\geq 35 \%$, and an increase in serum creatinine by $>50 \%$ for $<3$ months or evidence of structural kidney damage for $<3$ months [6]. These criteria are currently under revision (personal communication with the ADQI group).

\section{Diagnostic work-up}

As a syndrome, AKI can have multiple aetiologies. In critically ill patients, the most common causes are sepsis, heart failure, haemodynamic instability, hypovolaemia, and exposure to nephrotoxic substances [9]. Acute parenchymal and glomerular renal diseases are relatively rare. Determining the aetiology is essential to guide management and potentially target and influence the disease process. 
Table 3 New diagnostic biomarkers of AKI evaluated in human studies

\begin{tabular}{|c|c|c|c|}
\hline AKI biomarker & Description & Handling by the kidney & $\begin{array}{l}\text { Factors affecting biomarker } \\
\text { levels }\end{array}$ \\
\hline Alanine aminopeptidase (AAP) & \multirow{3}{*}{$\begin{array}{l}\text { Enzymes located on the brush border } \\
\text { villi of the proximal tubular cells }\end{array}$} & \multirow{3}{*}{$\begin{array}{l}\text { Released from tubular brush border } \\
\text { after damage to proximal tubular cells }\end{array}$} & \\
\hline Alkaline phosphatase (ALP) & & & \\
\hline Y-Glutamyl transpeptidase $(\gamma-G T)$ & & & \\
\hline Angiopoietin-1 & \multirow{3}{*}{$\begin{array}{l}57 \mathrm{kDa} \text { endothelial growth factor } \\
\text { secreted by endothelial cells, } \\
\text { including renal endothelial cells }\end{array}$} & \multirow{3}{*}{$\begin{array}{l}\text { Upregulated in glomerular disease } \\
\text { and sepsis }\end{array}$} & Systemic inflammation \\
\hline \multirow[t]{2}{*}{ Angiopoietin-2 } & & & Diabetes \\
\hline & & & Malignancy \\
\hline \multirow[t]{3}{*}{ Calprotectin } & \multirow{3}{*}{$\begin{array}{l}\text { Cytosolic calcium-binding complex } \\
\text { of two proteins of the S100 group } \\
\text { (S100A8/S100A9); derived from } \\
\text { neutrophils and monocytes; } \\
\text { activator of innate immune system }\end{array}$} & \multirow{3}{*}{$\begin{array}{l}\text { Detectable in urine following } \\
\text { intrinsic AKI }\end{array}$} & Inflammatory bowel disease \\
\hline & & & Urinary tract infection \\
\hline & & & CKD \\
\hline \multirow[t]{6}{*}{ Chitinase 3 -like protein 1} & \multirow{6}{*}{$\begin{array}{l}39 \mathrm{kDa} \text { soluble intracellular protein } \\
\text { of glycoside hydrolase family } 18 \\
\text { expressed by chrondrocytes, } \\
\text { macrophages, endothelial cells, } \\
\text { neutrophils, smooth muscle, and } \\
\text { cancer cells; }\end{array}$} & \multirow{6}{*}{$\begin{array}{l}\text { Glomerular filtration of serum } \\
\text { concentrations; in addition: some } \\
\text { secretion by macrophages within the } \\
\text { kidneys upon renal stress or damage }\end{array}$} & Inflammatory diseases \\
\hline & & & Malignancy \\
\hline & & & COPD \\
\hline & & & Liver cirrhosis \\
\hline & & & Connective tissue disease \\
\hline & & & Cardiovascular disease \\
\hline \multirow[t]{8}{*}{ Cystatin C } & \multirow{8}{*}{$\begin{array}{l}13 \mathrm{kDa} \text { cysteine protease inhibitor } \\
\text { produced by all nucleated human } \\
\text { cells and released into the plasma } \\
\text { at a constant rate }\end{array}$} & \multirow{8}{*}{$\begin{array}{l}\text { Freely filtered in glomeruli and } \\
\text { completely absorbed and } \\
\text { catabolized by proximal tubular cells; } \\
\text { no tubular resorption or secretion }\end{array}$} & Systemic inflammation \\
\hline & & & Malignancy \\
\hline & & & Thyroid disorders \\
\hline & & & Glucocorticoid disorder \\
\hline & & & Cigarette smoking \\
\hline & & & Hyperbilirubinaemia \\
\hline & & & Hypertriglyceridaemia \\
\hline & & & HIV disease \\
\hline a Glutathione S-transferase (a GST) & $\begin{array}{l}47-51 \mathrm{kDa} \text { cytoplasmic enzyme in } \\
\text { proximal tubule }\end{array}$ & $\begin{array}{l}\text { Released into urine following } \\
\text { tubular injury }\end{array}$ & \\
\hline п Glutathione S-transferase (п GST) & $\begin{array}{l}47-51 \mathrm{kDa} \text { cytoplasmic enzyme in } \\
\text { distal tubules }\end{array}$ & $\begin{array}{l}\text { Released into urine following } \\
\text { tubular injury }\end{array}$ & \\
\hline \multirow[t]{3}{*}{ Hepatocyte growth factor (HGF) } & \multirow{3}{*}{$\begin{array}{l}\text { Antifibrotic cytokine produced by } \\
\text { mesenchymal cells and involved in } \\
\text { tubular cell regeneration after AKI }\end{array}$} & \multirow{3}{*}{$\begin{array}{l}\text { Released into urine following } \\
\text { tubular injury }\end{array}$} & Advanced heart failure \\
\hline & & & Hypertension \\
\hline & & & Bowel inflammation \\
\hline \multirow[t]{2}{*}{ Hepcidin } & \multirow{2}{*}{$\begin{array}{l}2.78 \mathrm{kDa} \text { peptide hormone predominantly } \\
\text { produced in hepatocytes but also in } \\
\text { kidney, brain, and heart; regulator of iron } \\
\text { metabolism }\end{array}$} & \multirow{2}{*}{$\begin{array}{l}\text { Freely filtered followed by tubular } \\
\text { uptake and catabolism }\end{array}$} & Systemic inflammation \\
\hline & & & Iron overload \\
\hline $\begin{array}{l}\text { Insulin-like growth factor binding } \\
\text { protein-7 (IGFBP-7), tissue } \\
\text { metalloproteinase-2 (TIMP-2) }\end{array}$ & $\begin{array}{l}\text { Metalloproteinases involved in cell } \\
\text { cycle arrest }\end{array}$ & $\begin{array}{l}\text { Released into urine after tubular } \\
\text { cell stress }\end{array}$ & \\
\hline \multirow[t]{3}{*}{ Interleukin-18 (IL-18) } & \multirow[t]{3}{*}{18 kDa pro-inflammatory cytokine } & \multirow{3}{*}{$\begin{array}{l}\text { Released into urine by proximal } \\
\text { tubular cells following tubular injury }\end{array}$} & Inflammation \\
\hline & & & Sepsis \\
\hline & & & Heart failure \\
\hline \multirow[t]{4}{*}{ Kidney Injury Molecule-1 (KIM-1) } & \multirow{4}{*}{$\begin{array}{l}\text { Transmembrane glycoprotein } \\
\text { produced by proximal tubular } \\
\text { cells after ischaemic or } \\
\text { nephrotoxic injury }\end{array}$} & \multirow{4}{*}{$\begin{array}{l}\text { Released into urine following } \\
\text { ischaemic or nephrotoxic } \\
\text { tubular damage }\end{array}$} & Renal cell carcinoma \\
\hline & & & Chronic proteinuria \\
\hline & & & CKD \\
\hline & & & Sickle cell nephropathy \\
\hline
\end{tabular}


Table 3 New diagnostic biomarkers of AKI evaluated in human studies (Continued)

\begin{tabular}{|c|c|}
\hline $\begin{array}{l}\text { Liver-type fatty acid-binding } \\
\text { protein (L-FABP) }\end{array}$ & $\begin{array}{l}14 \mathrm{kDa} \text { intracellular lipid chaperone } \\
\text { produced in proximal tubular } \\
\text { cells and hepatocytes }\end{array}$ \\
\hline$a_{1}$ Microglobulin & $\begin{array}{l}\text { Low molecular weight protein } \\
\text { produced in liver }\end{array}$ \\
\hline$\beta_{2}$ Microglobulin & $\begin{array}{l}12 \text { kDa light chain of major } \\
\text { histocompatibility class I expressed } \\
\text { on cell surface of every nucleated cell }\end{array}$ \\
\hline MicroRNA & $\begin{array}{l}\text { Endogenous single-stranded } \\
\text { molecules of non-coding } \\
\text { nucleotides }\end{array}$ \\
\hline $\begin{array}{l}\text { Monocyte chemoattractant peptide-1 } \\
\text { (MCP-1) }\end{array}$ & $\begin{array}{l}\text { Peptide expressed in renal mesangial } \\
\text { cells and podocytes }\end{array}$ \\
\hline N-acetyl- $\beta$-D-glucosaminidase (NAG) & $\begin{array}{l}>130 \text { kDa lysosomal enzyme; produced } \\
\text { in proximal and distal tubular cells } \\
\text { and non-renal cells }\end{array}$ \\
\hline Neutrophil gelatinase-associated & At least three different types: \\
\hline lipocalin (NGAL) & $\begin{array}{l}\text { - Monomeric } 25 \mathrm{kDa} \text { glycoprotein } \\
\text { produced by neutrophils and epithelial } \\
\text { tissues, including renal tubular cells } \\
\text { - Homodimeric } 45 \mathrm{kDa} \text { protein produced } \\
\text { by neutrophils } \\
\text { - Heterodimeric } 135 \mathrm{kDa} \text { protein } \\
\text { produced by renal tubular cells }\end{array}$ \\
\hline
\end{tabular}

Netrin-1

Proenkephalin

Retinol binding protein (RBP)

Soluble triggering receptor expressed on myeloid cells-1 (sTREM-1) produced by renal tubular cells

50-75 kDa laminin-related molecule, minimally expressed in proximal tubular epithelial cells of normal kidneys

Endogenous polypeptide hormone in adrenal medulla, nervous system, immune system and renal tissue

21 kDa single-chain glycoprotein; synthesized by liver

Member of the immunoglobulin superfamily of receptors expressed on granulocytes and monocytes, also

\begin{abstract}
Freely filtered in glomeruli and reabsorbed in proximal tubular cells; increased urinary excretion after tubular cell damage
\end{abstract} possibly produced by endothelial cells and tubular epithelial cells
Freely filtered by glomeruli; reabsorbed and catabolised by proximal tubular cells; urinary excretion after tubular dysfunction

Freely filtered by glomeruli; reabsorbed and catabolised by proximal tubular cells; urinary excretion after tubular dysfunction

Upregulated following tubular injury and detectable in plasma and urine

Released into urine

Too large to undergo glomerular filtration; released into urine after tubular damage

25 kDa and 45 kDa NGAL undergo glomerular filtration and reabsorption in healthy tubular cells

$25 \mathrm{kDa}$ and $135 \mathrm{kDa}$ NGAL are released into urine following tubular damage

CKD

Polycystic kidney disease

Liver disease

Sepsis

Sepsis

Sepsis

Variety of primary renal diseases

Diabetic nephropathy

Sepsis

Malignancy

CKD

Urinary tract infection

Pancreatitis

COPD

Endometrial hyperplasia

Highly expressed in injured proximal tubules and released into urine

Cleared by glomerular filtration

Systemic inflammation

Pain

Totally filtered by the glomeruli and reabsorbed but not secreted by proximal tubules; released into urine following tubular injury

Diabetes

Obesity

Detectable in urine following glomerular filtration and possibly local production
Acute critical illness

Sepsis

Systemic inflammation
The terms "pre-renal", "renal" and "post-renal" have traditionally been used to narrow the differential diagnosis of AKI. It was a long-held view that "pre-renal AKI" or "transient" AKI were synonymous with "hypovolaemic AKI" and "fluid responsiveness" [49]. However, several studies have demonstrated that tubular damage may be present in patients with "pre-renal AKI" [50, 51]. Furthermore, adverse outcomes have been noted even when creatinine returned to baseline within $24 \mathrm{~h}$ [52]. Based on these results, the ADQI group proposed to differentiate between "functional AKI" and "kidney damage" in preference to the terms "pre-renal", "renal", and "post-renal" AKI [49].

The specific diagnostic workup in individual patients with AKI depends on the clinical context, severity, and duration of AKI, and also on local availability. Urinalysis, examination of the urinary sediment, and imaging studies should be performed as a minimum, with additional tests depending on the clinical presentation (Fig. 4). 


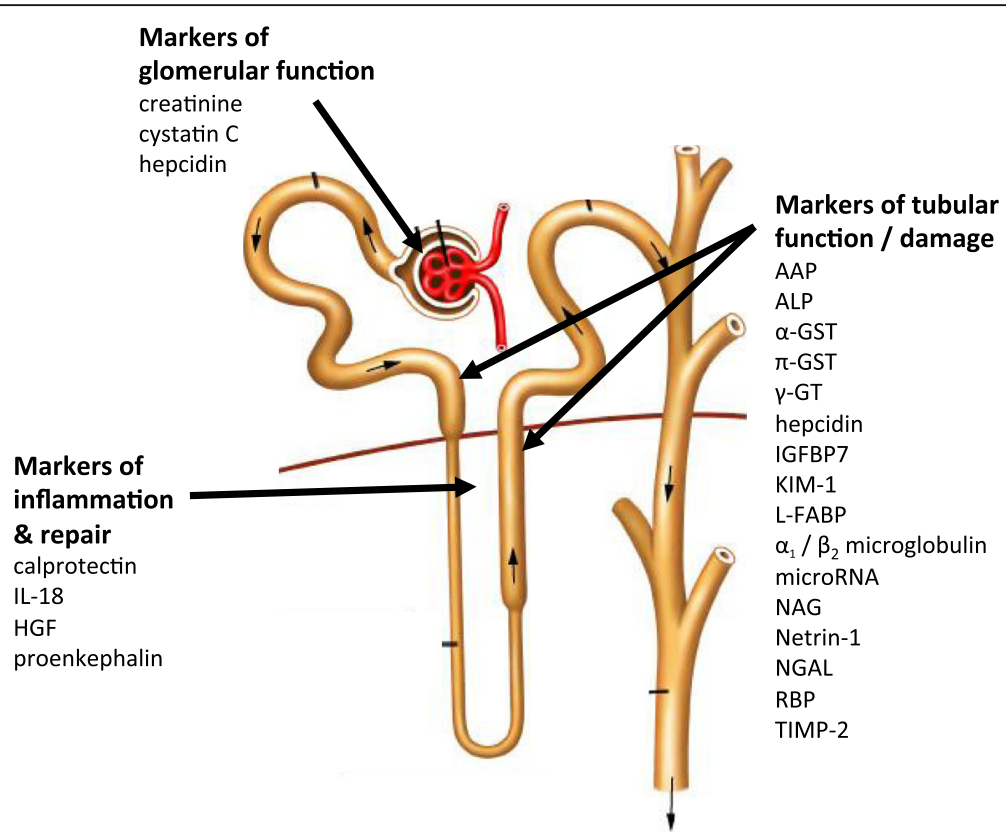

Fig. 2 Biomarkers of AKI. $a$-GST a glutathione S-transferase, AAP alanine aminopeptidase, ALP alkaline phosphatase, $\gamma$-GT $\gamma$-glutamyl transpeptidase, n GST $n$ glutathione S-transferase, HGF hepatocyte growth fator, IGFBP-7 insulin like growth factor binding protein 7, IL-18 interleukin 18, KIM-1 kidney injury molecule-1, L-FAB liver fatty acid-binding protein, NAG N-acetyl- $\beta$-D-glucosaminidase, NGAL neutrophil gelatinase-associated lipocalin, RBP retinol binding protein, TIMP2 tissue inhibitor metalloproteinase 2

\section{Urine dipstick}

Urine dipstick testing is a simple test to undertake. In fact, the AKI guideline by the National Institute for Health and Care Excellence (NICE) in the UK recommends performing urine dipstick testing for blood, protein, leucocytes, nitrites, and glucose in all patients as soon as AKI is suspected or detected in order not to miss any potentially treatable glomerular or tubular pathologies [53]. These include:

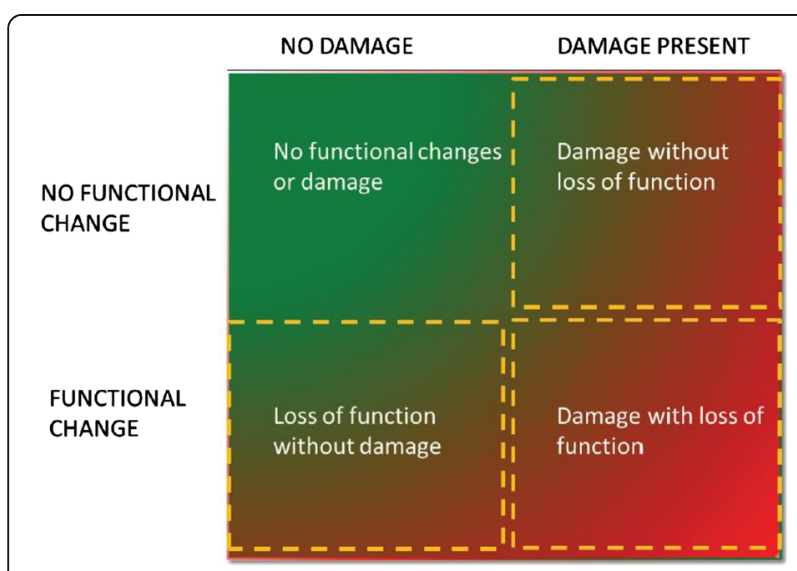

Fig. 3 Diagnosis of AKI based on functional and damage markers. The combination of functional and damage biomarkers allows the clinician to diagnose AKI earlier and to differentiate the disease process better. It is recognised that the process is dynamic and that patients may move from one phase to another. Reproduced with permission from http://www.adqi.org/
- glomerulonephritis (with haematuria and proteinuria)

- acute pyelonephritis (with pyuria/leucocyturia and nitrites in urine)

- interstitial nephritis (occasionally with eosinophiluria)

It is important to consider the result of the urine dipstick alongside the clinical history and an evaluation of the patient. For instance, the presence of white blood cells is non-specific but may indicate an underlying infection or acute interstitial nephritis. Similarly, dipstick haematuria in a patient with an indwelling urinary catheter can have multiple aetiologies ranging from glomerulonephritis to simple trauma. Dipsticks detect haemoglobin and remain positive even after red cell lysis. They also detect haemoglobinuria from intravascular haemolysis as well as myoglobin from muscle breakdown. A urine dipstick positive for haemoglobin without red blood cell positivity suggests a possible diagnosis of rhabdomyolysis.

\section{Urine microscopy (urinary sediment)}

Urine microscopy can provide very valuable information when performed by a skilled operator using a freshly collected non-catheterised urine sample (Table 4). It is not utilized very often in the ICU predominantly because it is operator dependent and requires training and experience. When done properly, the presence of red 


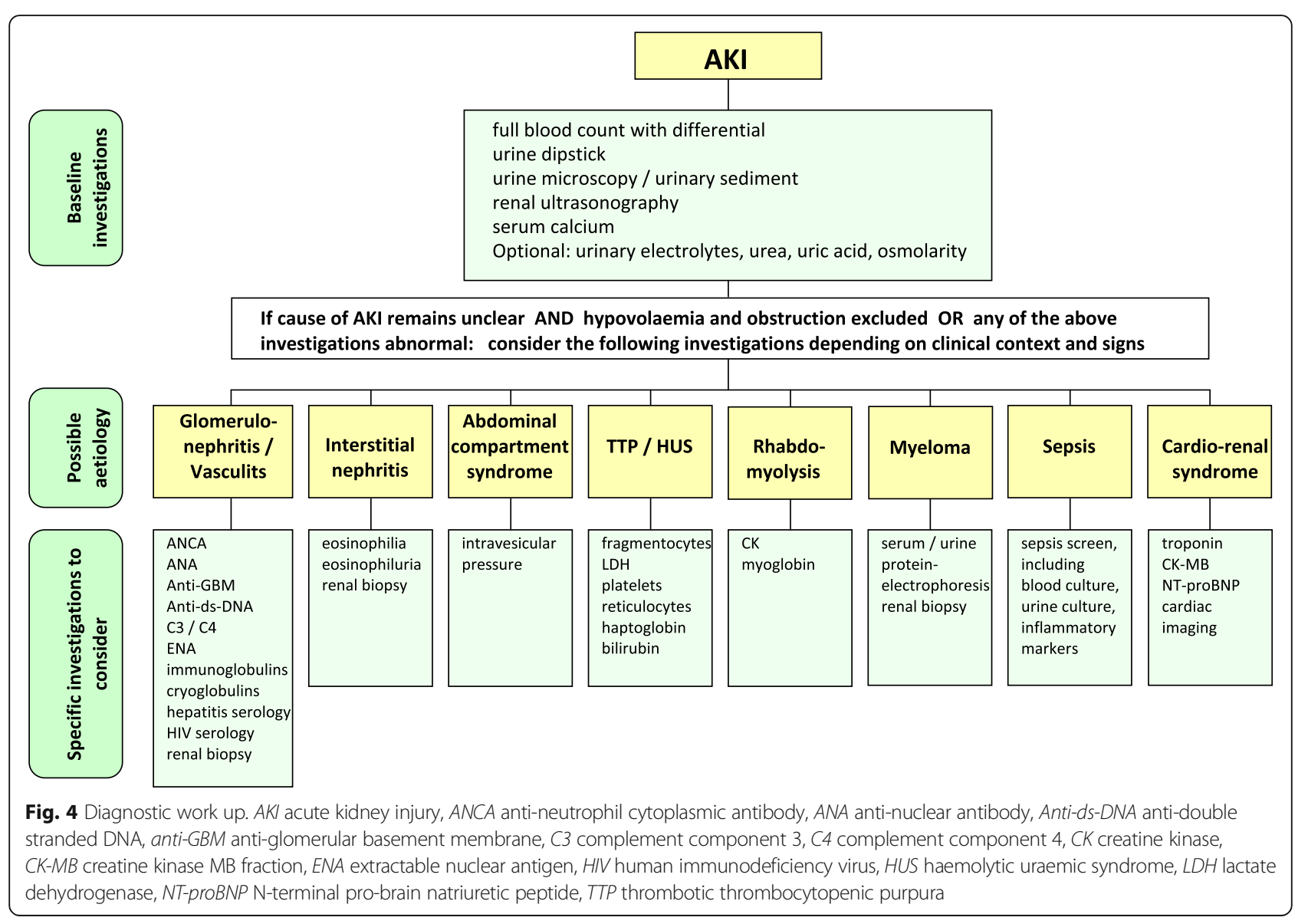

cell casts or dysmorphic red cells supports the diagnosis of glomerular disease [54-58]. Urine microscopy may also help to diagnose septic AKI and predict worsening renal function. Bagshaw and colleagues collected blood and urine samples of 83 critically ill patients with sepsis of whom $52 \%$ had AKI [55]. They derived a urine microscopy score based on the observed quantification of renal tubular epithelial cells and granular casts in the sediment and showed that septic AKI was associated with greater urine microscopy evidence of kidney injury compared with non-septic AKI, despite similar severity of AKI. A higher urine microscopy score was also predictive of worsening AKI. Finally, urine microscopy can be informative in rare cases of AKI; for instance, ethylene glycol poisoning where oxalate crystals may be seen, in case of tumour lysis syndrome where urate crystals may be present, or in light chain disease.

\section{Urinary electrolytes}

Measurement of urinary electrolytes and fractional excretion of sodium (FENa), urea, or uric acid has not been consistently shown to have clear correlations with clinical and histopathological findings [54, 59, 60]. In situations associated with transient hypovolaemia or hypoperfusion, healthy kidneys respond by increasing urine osmolarity and reducing sodium and/or urea or uric acid excretion. However, this physiological response may be variable and confounded by CKD and co-interventions, including diuretic therapy, aminoglycosides, and cardiopulmonary bypass [60-64]. Whereas the presence of low fractional sodium $(<1 \%)$, uric acid $(<12 \%)$, and urea excretion $(<34 \%)$ together with a normal urinary sediment may support the diagnosis of functional AKI, the absence of these typical urinary electrolyte abnormalities would not exclude it $[65,66]$. Finally, low FENa values have also been observed in experimental sepsis with increased renal blood flow as well as in the first hours of sepsis in humans [67-69].

As such, the interpretation of urinary electrolytes is challenging [70]. A single measurement of urinary electrolytes has a limited role in determining the differential diagnosis of AKI in critically ill patients. Instead, serial monitoring of urinary electrolytes may be more useful as sequential alterations in urine composition have been shown to parallel the development and severity of AKI [71, 72]. However, whether serial measurement of urine electrolytes can also help diagnosing the aetiology of AKI remains unclear. 
Table 4 Interpretation of urine microscopy findings

\begin{tabular}{lll}
\hline $\begin{array}{l}\text { Microscopy } \\
\text { finding }\end{array}$ & Example & Significance \\
\hline Epithelial cells & Normal \\
& & \\
& & \\
& &
\end{tabular}

Renal tubular cells

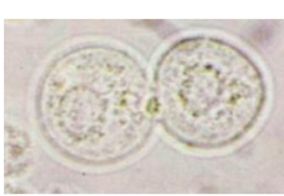

Acute tubular injury

Non-
dysmorphic red cells

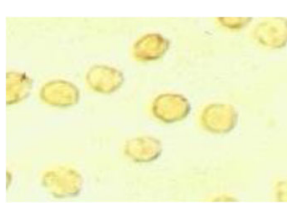

Non-glomerular bleeding from anywhere in the urinary tract Dysmorphic red
cells

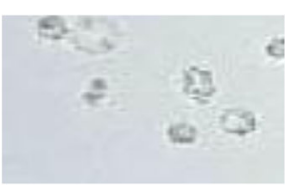

Glomerular disease, but can also be seen if urine sample is not fresh at time of microscopy

Red cell casts

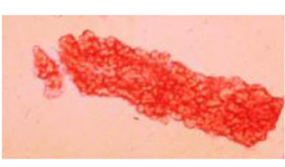

Diagnostic of glomerular disease

Leukocytes

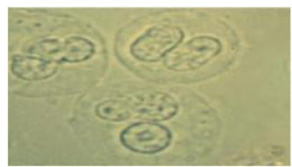

Up to 3 per high-power field $=$ normal; $>3$ per high-power field = inflammation in urinary tract

White cell casts

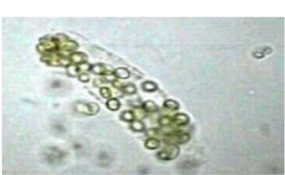

Renal infection

Hyaline casts

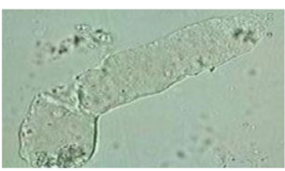

Table 4 Interpretation of urine microscopy findings (Continued)

Granular casts

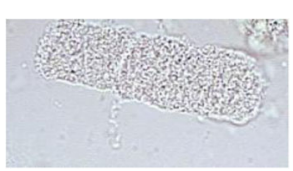

More significant renal disease
"Muddy brown cast"

Crystals

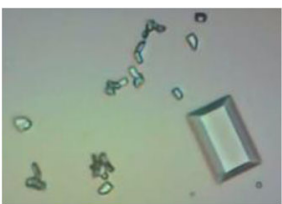

Bacteria

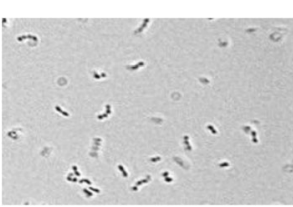

Necrotic tubular cells aggregated with tamm horsfall protein indicating acute tubular injury

\section{Renal ultrasound}

Renal ultrasonography is useful for evaluating existing structural renal disease and diagnosing obstruction of the urinary collecting system. In particular, the presence of reduced corticomedullary differentiation and decreased kidney size is indicative of underlying CKD. In patients with abdominal distension ultrasonography can be technically challenging, in which case other imaging studies will be necessary.

Renal Doppler ultrasound and contrast-enhanced ultrasound are two relatively new techniques that may be used at the bedside to estimate renal perfusion and renal cortical microcirculation, respectively [73-75]. The non-invasiveness, repeatability, and accessibility of these techniques appear promising, but broad clinical use is still limited by training requirements as well as uncertainty how to interpret the information obtained. Finally, although Doppler scans may detect the presence of reduced renal blood flow, they are of little use to determine the specific aetiology of AKI.

\section{Measurement of intra-abdominal pressure}

In case of suspected AKI due to intra-abdominal compartment syndrome, serial measurement of intra-abdominal pressure should be considered. Those with a pressure rise 
to $>20 \mathrm{mmHg}$ should be suspected of having AKI as a result of intra-abdominal compartment syndrome [76].

\section{Autoimmune profile}

Depending on the clinical context, clinical signs, and urine dipstick results, patients may require specific immunological tests, including anti-neutrophil cytoplasmic antibody (ANCA), anti-nuclear antibody (ANA), antiglomerular basement membrane antibody (anti-GBM), and complement component 3 and 4 to rule out immune-mediated diseases (i.e. vasculitis, connective tissue diseases) (Fig. 4). These investigations should be considered mandatory in patients with AKI presenting primarily with a pulmonary-renal syndrome, haemoptysis, or haemolysis/thrombocytopenia.

\section{Renal biopsy}

Renal biopsies are rarely performed in critically ill patients, mainly due to the perceived risk of bleeding complications and general lack of therapeutic consequences. However, a renal biopsy may offer information that is not available through other means and should be considered if underlying parenchymal or glomerular renal disease is suspected (Fig. 4). Interestingly, Chu et al. reported that diffuse histological changes of AKI could be present without a sufficient change in serum creatinine [47]. Among 303 patients with biopsy-proven acute parenchymal renal lesions, including crescentic glomerulonephritis and acute thrombotic microangiopathy, only 198 patients (65\%) met the KDIGO creatinine or urine criteria for AKI. In a separate study from France, about $50 \%$ of patients with AKI undergoing renal biopsy had a diagnosis distinct from acute tubular necrosis that frequently resulted in a change of treatment regimen [77]. Recent reports have suggested that transjugular renal biopsies may be safer than percutaneous or open techniques [78].

\section{Other laboratory tests}

Depending on the clinical context, the following tests may be indicated:

- serum creatine kinase and myoglobin (in case of suspected rhabdomyolysis)

- lactate dehydrogenase (LDH) (in case of suspected thrombotic thrombocytopenic purpura (TTP))

- fragmentocytes (in case of possible TTP/haemolytic uraemic syndrome (HUS))

- N-terminal pro-brain natriuretic peptide (NT-proBNP) and troponin (in case of suspected cardio-renal syndrome)

- serum/urine protein electrophoresis (in case of suspected myeloma kidney)
Challenges of diagnosing AKI in critically ill patients

As outlined earlier, the use of serum creatinine to estimate GFR in critically ill patients is limited by the lack of steady-state conditions, unpredictable rate of production, and variable degree of elimination (Table 2). Medications may cause increases in creatinine without reflecting a true decrease in GFR and fluid overload may lead to a dilution of creatinine concentrations. Finally, serum creatinine substantially lags behind a reduction in GFR and thus does not provide a useful real-time assessment of GFR. It is therefore not surprising that AKI is often diagnosed late in critically ill patients.

The interpretation of additional diagnostic investigations can be challenging, too. Dipstick haematuria is not uncommon in patients with an indwelling urinary catheter and most commonly due to simple trauma. Even more specialised tests, like autoimmune tests, have a higher risk of false-positive results in critically ill patients. For instance, infection is a frequent cause of a false-positive ANCA result [79]. Until more reliable tests are routinely used in clinical practice it is essential to interpret creatinine results and other diagnostic tests within the clinical context [80].

\section{Future diagnostic tools}

A variety of new functional and damage markers of AKI have been shown to provide information related to the underlying pathophysiology of AKI and may also be utilised as diagnostic tools. It is expected that some of these markers will be routinely integrated into the definition as well as diagnostic workup of AKI [49].

Achieving the ability to rapidly and accurately measure and monitor GFR in real time would be very beneficial, especially in the ICU [81, 82]. Several groups are developing optical measurement techniques using minimally invasive or non-invasive techniques that can quantify renal function independent of serum creatinine or urine output. In the past few years, significant progress has been made in using two-photon excitation fluorescence microscopy to study kidney function [82]. It is very likely that several of these approaches will enter clinical phase studies in the very near future. These techniques will enable an earlier diagnosis of AKI and also provide opportunities to improve clinical management, including the use of nephrotoxic substances and appropriate drug dosing.

New imaging techniques may also be utilised, including cine phase-contrast magnetic resonance imaging or intravital multiphoton studies [83, 84]. However, given the complexity, financial costs, and need for patient transport, it is likely that they will remain research tools.

\section{Conclusion}

Acute kidney injury is a clinical syndrome defined by a rise in serum creatinine and/or fall in urine output as 
per KDIGO classification. Future definitions are likely to incorporate novel functional and damage biomarkers to characterise AKI better. Early diagnosis and appropriate diagnostic work-up are essential to determine the underlying aetiology and to identify cases of AKI that require specific and timely therapeutic interventions. The exact diagnostic investigations depend on the clinical context and should include routine baseline tests as well as more specific and novel tools.

\begin{abstract}
Abbreviations
ADH: Anti-diuretic hormone; ADQI: Acute Dialysis Quality Initiative; AKD: Acute kidney disease; AKl: Acute kidney injury; AKIN: Acute Kidney Injury Network; ANCA: Anti-neutrophil cytoplasmic antibody; ANA: Anti-nuclear antibody; Anti-GBM: Anti-glomerular basement membrane; CKD: Chronic kidney disease; eGFR: Estimated glomerular filtration rate; FENa: fractional excretion of sodium; GFR: Glomerular filtration rate; HUS: Haemolytic uraemic syndrome; ICU: Intensive care unit; IGFBP-7: Insulin-like growth factor binding protein 7; KDIGO: Kidney Disease Improving Global Outcomes; LDH: Lactate dehydrogenase; KIM-1: Kidney injury molecule-1; L-FAB: Liver fatty acid-binding protein; NAG: N-acetyl- $\beta$-Dglucosaminidase; NGAL: Neutrophil gelatinase-associated lipocalin; NICE: National Institute for Health Care and Excellence; NT-proBNP: N-terminal pro-brain natriuretic peptide; RIFLE: Risk, Injury, Failure, Loss, End-stage; RRT: Renal replacement therapy; TIMP2: Tissue inhibitor metalloproteinase 2; TTP: Thrombotic thrombocytopenic purpura
\end{abstract}

\section{Authors' contributions}

$\mathrm{MO}$ and $\mathrm{MJ}$ jointly wrote the manuscript. Both authors read and approved the final manuscript.

\section{Competing interests}

The authors declare that they have no competing interests.

\section{Published online: 27 September 2016}

\section{References}

1. Singbartl K, Joannidis M. Short-term effects of acute kidney injury. Crit Care Clin. 2015;31(4):751-62.

2. Lewington AJ, Cerda J, Mehta RL. Raising awareness of acute kidney injury: a global perspective of a silent killer. Kidney Int. 2013;84(3):457-67.

3. Mehta RL, Cerda J, Burdmann EA, et al. International Society of Nephrology's Oby25 initiative for acute kidney injury (zero preventable deaths by 2025): a human rights case for nephrology. Lancet. 2015;385:2616-43.

4. Bellomo R, Ronco C, Kellum JA, et al. Acute renal failure: definition, outcome measures, animal models, fluid therapy and information technology needs: the second international consensus conference of the acute dialysis quality initiative (ADQI) group. Crit Care. 2004;8:R204-12.

5. Mehta RL, Kellum JA, Shah SV, et al. Acute kidney injury network: report of an initiative to improve outcomes in acute kidney injury. Crit Care. 2007;11:R31.

6. Kidney Disease: Improving Global Outcomes (KDIGO) Acute Kidney Injury Work Group. KDIGO clinical practice guideline for acute kidney injury. Kidney Int. 2012;2:1-138

7. Kellum JA, Sileanu FE, Murugan R, Lucko N, Shaw AD, Clermont G Classifying AKI by urine output versus serum creatinine level. J Am Soc Nephrol. 2015;26(9):2231-8.

8. Bastin AJ, Ostermann M, Slack AJ, Diller GP, Finney SJ, Evans TW. Acute kidney injury after cardiac surgery according to Risk/njury/Failure/Loss/Endstage, Acute Kidney Injury Network, and Kidney Disease: Improving Global Outcomes Classifications. J Crit Care. 2013;28(4):389-96.

9. Hoste EA, Bagshaw SM, Bellomo R, Cely CM, Colman R, Cruz DN, Edipidis K, Forni LG, Gomersall CD, Govil D, Honoré PM, Joannes-Boyau O, Joannidis M, Korhonen AM, Lavrentieva A, Mehta RL, Palevsky P, Roessler E, Ronco C, Uchino S, Vazquez JA, Vidal Andrade E, Webb S, Kellum JA. Epidemiology of acute kidney injury in critically ill patients: the multinational AKI-EPI study. Intensive Care Med. 2015:41(8):1411-23.

10. Joannidis M, Metnitz B, Bauer P, Schusterschitz N, Moreno R, Druml W, Metnitz PG. Acute kidney injury in critically ill patients classified by AKIN versus RIFLE using the SAPS 3 database. Intensive Care Med. 2009;35(10):1692-702.
11. Joannidis M, Metnitz PG. Epidemiology and natural history of acute renal failure in the ICU. Crit Care Clin. 2005;21(2):239-49.

12. Ostermann M, Chang R, Riyadh ICU. Program Users Group. Correlation between the AKI classification and outcome. Crit Care. 2008;12(6):R144.

13. Ostermann $\mathrm{M}$, Chang RW. Acute kidney injury in the intensive care unit according to RIFLE. Crit Care Med. 2007;35(8):1837-43.

14. Ostermann M. Diagnosis of acute kidney injury: Kidney Disease Improving Global Outcomes criteria and beyond. Curr Opin Crit Care. 2014;20(6):581-7.

15. Thomas M, Blaine C, Dawnay A, Devonald MA, Ftouh S, Laing C, Latchem S, Lewington A, Milford DV, Ostermann M. The definition of acute kidney injury and its use in practice. Kidney Int. 2015;87:62-73.

16. Clark WR, Mueller BT, Kraus MA, Macias WL. Quantification of creatinine kinetic parameters in patients with acute renal failure. Kidney Int. 1998;54(2):554-60.

17. Schetz M, Gunst J, Van den Berghe G. The impact of using estimated GFR versus creatinine clearance on the evaluation of recovery from acute kidney injury in the ICU. Intensive Care Med. 2014;40(11):1709-17.

18. Doi K, Yuen PS, Eisner C, Hu X, Leelahavanichkul A, Schnermann J, Star RA. Reduced production of creatinine limits its use as marker of kidney injury in sepsis. J Am Soc Nephrol. 2009:20(6):1217-21.

19. Liu KD, Thompson BT, Ancukiewicz M, et al. Acute kidney injury in patients with acute lung injury: impact of fluid accumulation on classification of acute kidney injury and associated outcomes. Crit Care Med. 2011;39:2665-71.

20. Macedo E, Bouchard J, Soroko SH, et al. Fluid accumulation, recognition and staging of acute kidney injury in critically-ill patients. Crit Care. 2010;14:R82.

21. Siew ED, Matheny ME. Choice of reference serum creatinine in defining acute kidney injury. Nephron. 2015;131:107-12.

22. Bagshaw SM, Uchino S, Cruz D, et al. A comparison of observed versus estimated baseline creatinine for determination of RIFLE class in patients with acute kidney injury. Nephrol Dial Transplant. 2009;24: 2739-44.

23. Zavada J, Hoste E, Cartin-Ceba R, Calzavacca P, Gajic O, Clermont G, Bellomo $R$, Kellum JA, for the AKI6 Investigators. A comparison of three methods to estimate baseline creatinine for RIFLE classification. Nephrol Dial Transplant. 2010;25:3911-8.

24. Palevsky P, Liu KD, Brophy PD, et al. KDOQI US commentary on the 2012 KDIGO clinical practice guideline on acute kidney injury. Am J Kidney Dis. 2013:61:649-72.

25. Prowle JR, Liu YL, Licari E, Bagshaw SM, Egi M, Haase M, Haase-Fielitz A, Kellum JA, Cruz D, Ronco C, Tsutsui K, Uchino S, Bellomo R. Oliguria as predictive biomarker of acute kidney injury in critically ill patients. Crit Care. 2011;15(4):R172.

26. Zaloga GP, Hughes SS. Oliguria in patients with normal renal function. Anesthesiology. 1990;72(4):598-602.

27. Guay J, Lortie L. Activation of the renin-angiotensin system contributes significantly to the pathophysiology of oliguria in patients undergoing posterior spinal fusion. Eu J Anaesthesiol. 2004;21(10):812-8.

28. Lehner GF, Forni LG, Joannidis M. Oliguria and biomarkers of acute kidney injury: star struck lovers or strangers in the night? Nephron. 2016;133(4). [Epub ahead of print].

29. Md Ralib A, Pickering JW, Shaw GM, Endre ZH. The urine output definition of acute kidney injury is too liberal. Crit Care. 2013;17:112.

30. Fliser D, Laville M, Covic A, et al. A European Renal Best Practice (ERBP) position statement on the Kidney Disease Improving Global Outcomes (KDIGO) clinical practice guidelines on acute kidney injury: part 1: definitions, conservative management and contrast-induced nephropathy. Nephrol Dial Transplant. 2012;27(12):4263-72.

31. Ostermann M, Joannidis M. Biomarkers for AKI improve clinical practice: no. Intensive Care Med. 2015;41(4):618-22.

32. Ostermann M, Philips BJ, Forni LG. Clinical review: biomarkers of acute kidney injury: where are we now? Crit Care. 2012;16:233.

33. Charlton JR, Portilla D, Okusa MD. A basic science view of acute kidney injury biomarkers. Nephrol Dial Transplant. 2014;29:1301-11.

34. Delanaye P, Cavalier E, Morel J, Mehdi M, Maillard N, Claisse G, Lambermont B, Dubois BE, Damas P, Krzesinski JM, Lautrette A, Mariat C. Detection of decreased glomerular filtration rate in intensive care units: serum cystatin C versus serum creatinine. BMC Nephrol. 2014;15:9.

35. Murray PT, Mehta RL, Shaw A, et al. Current use of biomarkers in acute kidney injury: report and summary of recommendations from the 10th Acute Dialysis Quality Initiative consensus conference. Kidney Int. 2014:85:513-21. 
36. Van Veldhuisen DJ, Ruilope LM, Maisel AS, Damman K. Biomarkers of renal injury and function: diagnostic, prognostic and therapeutic implications in heart failure. Eur Heart J. 2015 [Epub ahead of print].

37. Kashani K, Al-Khafaji A, Ardiles T, et al. Discovery and validation of cell cycle arrest biomarkers in human acute kidney injury. Crit Care. 2013;17:R25.

38. Haase M, Devarajan P, Haase-Fielitz A, Bellomo R, Cruz DN, Wagener G, Krawczeski CD, Koyner JL, Murray P, Zappitelli M, Goldstein SL, Makris K, Ronco C, Martensson J, Martling CR, Venge P, Siew E, Ware LB, Ikizler TA Mertens PR. The outcome of neutrophil gelatinase-associated lipocalinpositive subclinical acute kidney injury: a multicenter pooled analysis of prospective studies. J Am Coll Cardiol. 2011;57:1752-61.

39. Haase M, Kellum JA, Ronco C. Subclinical AKL_an emerging syndrome with important consequences. Nat Rev Nephrol. 2012;8:735-9.

40. McCullough PA, Shaw AD, Haase M, et al. Diagnosis of acute kidney injury using functional and injury biomarkers: workgroup statements from the tenth acute dialysis quality initiative consensus conference. Contrib Nephrol. 2013;182:13-29.

41. Vanmassenhove J, Glorieux G, Lameire N, Hoste E, Dhondt A, Vanholder R, Van Biesen W. Influence of severity of illness on neutrophil gelatinaseassociated lipocalin performance as a marker of acute kidney injury: a prospective cohort study of patients with sepsis. BMC Nephrol. 2015;16:18.

42. Leelahavanichkul A, Souza AC, Street JM, Hsu V, Tsuji T, Doi K, Li L, Hu X, Zhou H, Kumar P, Schnermann J, Star RA, Yuen PS. Comparison of serum creatinine and serum cystatin $C$ as biomarkers to detect sepsis-induced acute kidney injury and to predict mortality in CD-1 mice. Am J Physiol Renal Physiol. 2014;307(8):F939-48.

43. Kos J, Stabuc B, Cimerman N, Brünner N. Serum cystatin C, a new marker of glomerular filtration rate, is increased during malignant progression. Clin Chem. 1998;44(12):2556-7.

44. Fricker $M$, Wiesli $P$, Brändle $M$, Schwegler B, Schmid C. Impact of thyroid dysfunction on serum cystatin C. Kidney Int. 2003;63(5):1944-7.

45. Bökenkamp A, van Wijk JA, Lentze MJ, Stoffel-Wagner B. Effect of corticosteroid therapy on serum cystatin $C$ and beta2-microglobulin concentrations. Clin Chem. 2002;48(7):1123-6.

46. Knight EL, Verhave JC, Spiegelman D, Hillege HL, de Zeeuw D, Curhan GC, de Jong PE. Factors influencing serum cystatin $C$ levels other than renal function and the impact on renal function measurement. Kidney Int. 2004;65(4):1416-21.

47. Chu R, Li C, Wang S, et al. Assessment of KDIGO definitions in patients with histopathologic evidence of acute renal disease. Clin J Am Soc Nephrol. 2014:9:1175-82

48. Ostermann M, Chang RW. Challenges of defining acute kidney injury. QJM. 2011;104:237-43.

49. Endre ZH, Kellum JA, Di Somma S, Doi K, Goldstein SK, Koyner JL, Macedo E, Mehta RL, Murray PT. Differential diagnosis of AKI in clinical practice by functional and damage biomarkers: workgroup statements from the tenth Acute Dialysis Quality Initiative Consensus Conference. Contrib Nephrol. 2013;182:30-44.

50. Legrand M, Mik EG, Balestra GM, Lutter R, Pirracchio R, Payen D, Ince C. Fluid resuscitation does not improve renal oxygenation during haemorrhagic shock in rats. Anesthesiology. 2010;112:119.

51. Nejat M, Pickering JW, Devarajan P, Bonventre JV, Edelstein CL, Walker RJ, Endre $\mathrm{ZH}$. Some biomarkers of acute kidney injury are increased in pre-renal acute injury. Kidney Int. 2012;81:1254-62.

52. Uchino S, Bellomo R, Bagshaw SM, Goldsmith D. Transient azotaemia is associated with a high risk of death in hospitalized patients. Nephrol Dial Transplant. 2010;25:1833-9.

53. National Clinical Guideline Centre. Acute kidney injury: prevention, detection and management of acute kidney injury up to the point of renal replacement therapy. Clinical guidelines, CG169. Available from: https://www.nice.org.uk/guidance/CG169. Accessed 18 Sept 2016.

54. Bagshaw SM, Gibney RT. Acute kidney injury: clinical value of urine microscopy in acute kidney injury. Nat Rev Nephrol. 2009;5:185-6.

55. Bagshaw SM, Haase M, Haase-Fielitz A, Bennett M, Devarajan P, Bellomo R. A prospective evaluation of urine microscopy in septic and non-septic acute kidney injury. Nephrol Dial Transplant. 2012;27(2):582-8.

56. Luciano RL, Castano E, Fogazzi GB, Perazella MA. Light chain crystalline kidney disease: diagnostic urine microscopy as the "liquid kidney biopsy". Clin Nephrol. 2014;82(6):387-91.

57. Perazella MA. The urine sediment as a biomarker of kidney disease. Am J Kidney Dis. 2015;66(5):748-55.
58. Sharda N, Bakhtar O, Thajudeen B, Meister E, Szerlip H. Manual urine microscopy versus automated urine analyzer microscopy in patients with acute kidney injury. Lab Med. 2014;45(4):e152-5.

59. Bagshaw SM, Langenberg C, Wan L, May CN, Bellomo R. A systematic review of urinary findings in experimental septic acute renal failure. Crit Care Med. 2007;35:1592-8.

60. Bagshaw SM, Langenberg C, Bellomo R. Urinary biochemistry and microscopy in septic acute renal failure: a systematic review. Am J Kidney Dis. 2006;48:695-705.

61. Carvounis CP, Nisar S, Guro-Razuman S. Significance of the fractional excretion of urea in the differential diagnosis of acute renal failure. Kidney Int 2002:62:2223-9.

62. Pe'pin MN, Bouchard J, Legault L, Ethier J. Diagnostic performance of fractional excretion of urea and fractional excretion of sodium in the evaluations of patients with acute kidney injury with or without diuretic treatment. Am J Kidney Dis. 2007:50:566-73.

63. Diskin CJ, Stokes TJ, Dansby LM, Radcliff L, Carter TB. Toward the optimal clinical use of the fraction excretion of solutes in oliguric azotemia. Ren Fail. 2010;32:1245-54.

64. Prowle J, Bagshaw SM, Bellomo R. Renal blood flow, fractional excretion of sodium and acute kidney injury: time for a new paradigm? Curr Opin Crit Care. 2012;18(6):585-92.

65. Fenske W, Störk S, Koschker AC, Blechschmidt A, Lorenz D, Wortmann S, Allolio B. Value of fractional uric acid excretion in differential diagnosis of hyponatremic patients on diuretics. J Clin Endocrinol Metab. 2008;93(8):2991-7.

66. Hall IE, Coca SG, Perazella MA, et al. Risk of poor outcomes with novel and traditional biomarkers at clinical AKI diagnosis. Clin J Am Soc Nephrol. 2011;6:2740-9.

67. Langenberg C, Wan L, Egi M, May CN, Bellomo R. Renal blood flow in experimental septic acute renal failure. Kidney Int. 2006;69(11):1996-2002.

68. Langenberg C, Wan L, Bagshaw SM, Egi M, May CN, Bellomo R. Urinary biochemistry in experimental septic acute renal failure. Nephrol Dial Transplant. 2006;21(12):3389-97.

69. Vanmassenhove J, Glorieux G, Hoste E, Dhondt A, Vanholder R, Van Biesen W. Urinary output and fractional excretion of sodium and urea as indicators of transient versus intrinsic acute kidney injury during early sepsis. Crit Care. 2013;17(5):R234

70. Maciel AT, Vitorio D. Urine biochemistry assessment in critically ill patients: controversies and future perspectives. J Clin Monit Comput. 2016. [Epub ahead of print].

71. Maciel AT, Vitorio D. Urine biochemistry in the early postoperative period after cardiac surgery: role in acute kidney injury monitoring. Case Rep Crit Care. 2013;2013:103450.

72. Maciel AT, Park M, Macedo E. Physicochemical analysis of blood and urine in the course of acute kidney injury in critically ill patients: a prospective, observational study. BMC Anesthesiol. 2013;13(1):31.

73. Schnell D, Darmon M. Bedside Doppler ultrasound for the assessment of renal perfusion in the ICU: advantages and limitations of the available techniques. Crit Ultrasound J. 2015:7(1):24

74. Göcze I, Renner P, Graf BM, Schlitt HJ, Bein T, Pfister K. Simplified approach for the assessment of kidney perfusion and acute kidney injury at the bedside using contrast-enhanced ultrasound. Intensive Care Med. 2015;41(2):362-3.

75. Schneider AG, Goodwin MD, Schelleman A, Bailey M, Johnson L, Bellomo R. Contrast-enhanced ultrasonography to evaluate changes in renal cortical microcirculation induced by noradrenaline: a pilot study. Crit Care. 2014;18(6):653.

76. Kirkpatrick AW, Roberts DJ, De Waele J, et al. Intra-abdominal hypertension and the abdominal compartment syndrome: updated consensus definitions and clinical practice guidelines form the World Society of the Abdominal Compartment Syndrome. Intensive Care Med. 2013;39(7):1190-206.

77. Augusto JF, Lassalle V, Fillatre P, Perrotin D, Meziani F, Schenck-Dhif M, Bollaert PE, du Cheyron D, Beduneau G, Vinsonneau C, Guitton C, Lerolle N. Safety and diagnostic yield of renal biopsy in the intensive care unit. Intensive Care Med. 2012;38(11):1826-33.

78. Javaid MM, Johnston M, Kalsi N, Venn RM, Forni LG. Acute kidney injury on the intensive care unit: the use of transjugular renal biopsy in aiding diagnosis. Netherlands J Crit Care. 2011;2:61-5.

79. Chirinos JA, Corrales-Medina VF, Garcia S, Lichtstein DM, Bisno AL, Chakko S. Endocarditis associated with antineutrophil cytoplasmic antibodies: a case report and review of the literature. Clin Rheumatol. 2007;26(4):590-5.

80. Schmitt WH, van der Woude FJ. Clinical applications of antineutrophil cytoplasmic antibody testing. Curr Opin Rheumatol. 2004;16(1):9-17.

81. Molitoris BA. Measuring glomerular filtration rate in the intensive care unit: no substitute please. Crit Care. 2013;17:181. 
82. Molitoris BA, Reilly ES. Quantifying glomerular filtration rates in acute kidney injury: a requirement for translational success. Semin Nephrol. 2016;36(1):31-41.

83. Prowle JR, Molan MP, Hornsey E, Bellomo R. Cine phase-contrast magnetic resonance imaging for the measurement of renal blood flow. Contrib Nephrol. 2010;165:329-36.

84. Molitoris BA, Sandoval RM. Techniques to study nephron function: microscopy and imaging. Pflugers Arch. 2009;458:203-9. 